\title{
Association between functional balance and knee extensors strength in people with Parkinson's disease
}

\section{Associação entre o equilíbrio funcional e a força dos extensores do joelho em pessoas com a doença de Parkinson}

\section{Asociación entre el equilibrio funcional y la fuerza de los extensores de la rodilla en personas con la enfermedad de Parkinson}

\section{Sacha Clael (1) ', Filipe Dinato de Lima (i) ', Elaine Cristina da Silva Brandão (1) ', Jhonatan Conrado Rodrigues (1) ', Camila Wells Damato Marcelino (i) ', Rafaela do Vale Pinheiro ${ }^{2}$, José Celi Neto $(1)$, Lídia Mara Aguiar Bezerra $\left(\mathbb{1}^{1}\right.$}

' University of Brasília (UNB). Brasilia, DF, Brazil.

2 Catholic University of Brasília (UCB). Brasília, DF. Brazil.

3 The University of Matanzas (UM). Matanzas, MTZ, Cuba.

\section{ARTICLE INFO}

\section{Article history}

Received: 29/10/2018

Accepted: 28/01/2019

Published: 21/05/2019

\section{$\triangle$ Correspondent Author}

Sacha Clael

University of Brasilia (UNB)

Faculty of Physical Education - Asa Norte

70910-900, Brasília, DF, Brazil

sachaclael@hotmail.com

(C) 2019 All rights reserved

\section{Editors}

Alfredo Cataldo Neto

Paula Engroff

\begin{abstract}
AIMS: The aim of this study is to verify if there is a correlation between functional balance and muscular strength of knee extensors in individuals with Parkinson's disease.

METHODS: The sample consisted of 28 volunteers with Parkinson's disease (age: $65.43 \pm 8.48$ years, height: $1.68 \pm 0.10 \mathrm{~cm}$, weight: $71.50 \pm 13.27 \mathrm{~kg}$ ) classified on the modified Hoehn \& Yahr scale. The Four Step Square Test and the isokinetic dynamometer were used to evaluate the dynamic balance and muscular strength of knee extensors, respectively.

RESULTS: The peak torque shows a moderate, negative and significant correlation with the Four Step Square Test (right knee: $r=-0.471$ and $p=0.012$; left knee: $r=-0.444$ and $p=0.018)$

CONCLUSIONS: There is a negative, moderate and significant association between muscular strength of knee extensors and dynamic balance in Parkinson's disease individuals.

KEYWORDS: Muscle Strength Dynamometer; Neurotransmitter Agents; Nerve Degeneration; Substantia Nigra; Activities of Daily Living.
\end{abstract}

\section{RESUMO}

OBJETIVOS: O objetivo deste estudo é verificar se há correlação entre o equilíbrio funcional e a força muscular de extensores de joelho em indivíduos com doença de Parkinson.

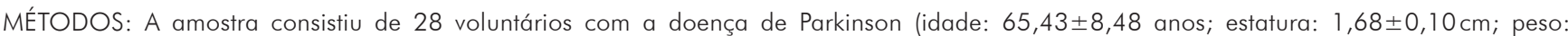
$71,50 \pm 13,27 \mathrm{~kg}$ ) classificados na escala de Hoehn \& Yahr modificada. O Four Step Square Test e o dinamômetro isocinético foram utilizados para avaliar o equilíbrio dinâmico e a força muscular dos extensores do joelho, respectivamente.

RESULTADOS: $\bigcirc$ pico de torque mostra uma correlação moderada, negativa e significante com Four Step Square Test (joelho direito: $r=-0,471$ e $p=0,012$; joelho esquerdo: $r=-0,444$ e $p=0,018)$.

CONCLUSÕES: Há uma associação negativa, moderada e significativa entre a força muscular de extensores de joelho e o equilíbrio dinâmico em indivíduos com doença de Parkinson.

PalaVRas-CHAVE: Dinamômetro de Força Muscular; Neurotransmissores; Degeneração Neural; Substância Negra; Atividades Cotidianas. 


\section{RESUMEN}

OBJETIVOS: El objetivo de este estudio es verificar si hay correlación entre el equilibrio funcional y la fuerza muscular de extensores de la rodilla en individuos con la enfermedad de Parkinson.

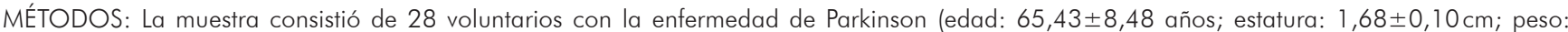
$71,50 \pm 13,27 \mathrm{~kg}$ ) clasificados en la escala de Hoehn \& Yahr modificada. El Four Step Square Test y el dinamómetro isocinético fueron utilizados para evaluar el equilibrio dinámico y la fuerza muscular de los extensores de la rodilla, respectivamente.

RESULTADOS: El pico de torque muestra una correlación moderada, negativa y significante con el Four Step Square Test (rodilla derecha: $r=-0,471$ y $p=0,012$; rodilla izquierda: $r=-0,444$ e $p=0,018)$.

CONCLUSIONES: Hay una asociación negativa, moderada y significativa entre la fuerza muscular de extensores de rodilla y el equilibrio dinámico en individuos con la enfermedad de Parkinson.

Palabras Clave: Dinamómetro de Fuerza Muscular; Neurotransmisores; Degeneración Nerviosa; Sustancia Negra; Actividades Cotidianas.

\section{INTRODUCTION}

Parkinson's disease (PD) is a neurodegenerative disease characterized by progressive deterioration of the substantia nigra in the midbrain which causes a decrease in dopamine production ${ }^{1}$. Because of this brain change, people with PD may have motor deficits in posture and balance, including bradykinesia, hypokinesia, gait freezing, stiffness, tremors, and instability ${ }^{2}$. Moreover, some studies report a deficit of muscular strength in people with PD when compared to neurologically healthy groups ${ }^{3,4}$.

The weakness regarding PD may result from both central and peripheral factors, affecting both the process and the send of information, in addition to the movements execution ${ }^{5}$. Hence, this muscle weakness tends to compromise the ability to perform activities of daily living as well as the increased risk of falls ${ }^{6}$. Furthermore, individuals with PD have balance flaw, a common feature that favors autonomy loss ${ }^{2}$.

Deterioration of the basal ganglia produces an increased inhibitory pattern, causing difficulties in modulating the balance strategies ${ }^{7}$, because of these changes, individuals with PD tend to shift the gravity center to forward ${ }^{8}$. As a result of these conditions, is impossible for a person with PD to plan and execute compensatory movements to recover balance and stability, which may lead to falls ${ }^{9}$.

The literature reports that strength is related to mobility for people with $\mathrm{PD}^{6}$, however, most of the studies are performed with computerized posturography ${ }^{10-12}$, which most clinics and training centers do not have access. Thus, there is need to study dynamic balance and its relationship with strength, through a test with low cost, easy reproducibility and with the possibility of diversified movements ( $x$ and $y$ axis), that imitate day-to-day actions and allow greater security for the people with PD.
The Four Step Square Test (FSST) is a functional balance test which demands a subject to move sideways, forwards and backwards overcoming obstacles in a specified sequence, moreover to apply the test only 4 canes and one stopwatch are required ${ }^{13}$. Thus, it increases the applicability of the test, already being used in different populations, such vestibular disorders ${ }^{14}$, stroke ${ }^{15}$ and $\mathrm{PD}^{16}$.

Studies report an increase in muscle strength as a result of an adequate training program ${ }^{17,18}$, which lead effectively to improve physical capabilities ${ }^{19}$, including balance ${ }^{20}$. Moreover, the PD deficits can cause loss of mobility and the influence on strength ${ }^{2}$. Thus, the aim of this study is to verify if there is a correlation between functional balance and muscular strength of knee extensors in individuals with PD.

\section{METHODS}

The sample consist of 28 individuals with a clinical diagnosis of PD, they were classified on the modified Hoehn \& Yahr scale ${ }^{21}$. The volunteers were instructed not to perform physical exercises on 24 hours prior to the tests protocols. The Mini Mental State Examination was used to screen for mild cognitive impairment of participants and the criterion for inclusion in the study was established as a score $>24$ points $^{22}$. As the test is influenced by educational level, inclusion scores were adjusted to $>19$ points for illiterate individuals ${ }^{23}$.

The subjects needed to visit laboratory 2 times, with 48 hours of interval, first for anthropometric measurements, anamnesis and strength test, and second for functional test. All the participants were evaluated in "on" medication period, and this study was approved by the Faculty of Health Sciences at University of Brasilia ethics committee (number: 79851717.2.0000.0030) and all volunteers signed the consent form. 
The level of physical activity was measured using the International Physical Activity Questionnaire (IPAQ) and the model used was the short version. In order to classify the obtained results, the division into four groups was used: 1) very active; 2) active; 3) insufficiently active; 4) sedentary ${ }^{24}$.

To assess dynamic balance the FSST was used, the volunteer starts on square 1 and is required to step as fast as possible into each square in the following sequence: 2, 3, 4, 1, 4, 3, 2, and 1 (Figure 1). The researcher performed the test once as a demonstration and the volunteer performed a sequence for familiarization. Two trials were performed and the fastest time was used $^{25}$.

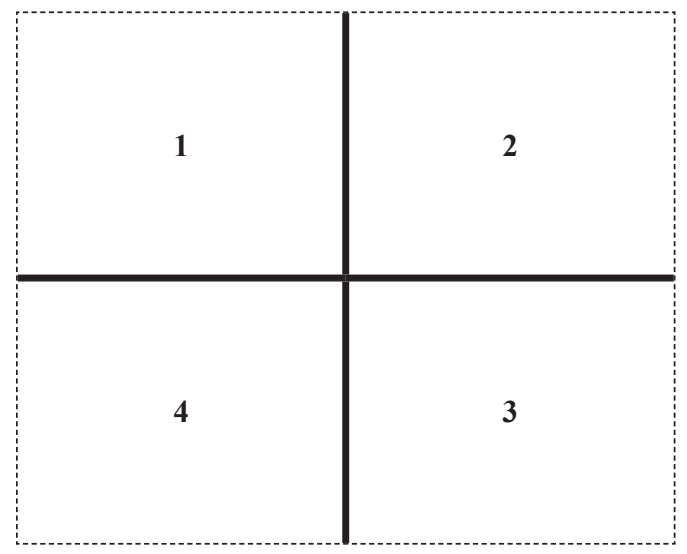

Figure 1. Four Step Square Test.

To assess muscular strength of knee extensors the Biodex system III Isokinetic Dynamometer (Biodex Medical, Inc., Shirley, NY) was used with the protocol adapted from Malicka et al. ${ }^{26}$ and were performed only in the concentric phase. Moreover, all the warm-ups and trials had 60 seconds of rest interval. The participants performed 2 trials on each leg and the protocol was counterbalanced.

Warm-up: 1 set of 10 repetitions at $180 \%$ s as follows, was ordered for the volunteer to do one maximum contraction, and then it was ordered to do 9 more contractions between $50 \%$ and $60 \%$ of the maximal effort. Test: 2 sets of 4 repetitions at $60 \% / s$. The trial with the highest value was used to determine the absolute torque peak (PT).

For sample characterization, descriptive statistics were performed with mean and standard deviation for quantitative variables, and simple frequency for qualitative variables. To verify data normality the Shapiro-Wilk test was used. The Pearson correlation of the functional balance and muscular strength of knee extensors was performed. The statistical significance level was set at $p<0.05$ in all correlations.

\section{RESULTS}

Sample characteristics are described in Table 1.

Table 1. Sample characterization.

\begin{tabular}{lc}
\hline & Mean \pm Standard Deviation \\
Age (year) & $65.43 \pm 8.48$ \\
Weight (kilogram) & $71.50 \pm 13.27$ \\
Height (meter) & $1.68 \pm 0.10$ \\
FSST (second) & $9.41 \pm 1.62$ \\
PT right side (Newton.meters) & $131.80 \pm 47.85$ \\
PT left side (Newton.meters) & $122.99 \pm 44.08$ \\
Gender (frequency) & \\
Men & 20 \\
Women & 8 \\
Hoehn \& Yard (frequency) & \\
Level 1 & 3 \\
Level 1.5 & 4 \\
Level 2 & 9 \\
Level 2.5 & 8 \\
Level 3 & 4 \\
IPAQ (frequency) & \\
Very active & 3 \\
Active & 14 \\
Insufficiently active & 7 \\
Sedentary & 4 \\
\hline
\end{tabular}

IPAQ: International Physical Activity Questionnaire; FSST: Four Step Square Test.

Figure 2 shows correlation between functional balance with muscular strength of knee extensors (right knee: $r=-0.471$ and $p=0.012$; left knee: $r=-0.444$ and $p=0.018$ ), and all correlations are significant, $p<0.05$. The PT shows a moderate, negative and significant correlation with the FSST (Figure 2).

\section{DISCUSSION}

The objective of this study was to verify if there is a correlation between functional balance and muscular strength of knee extensors in individuals with PD, and we observed that subjects who demonstrated higher PT, also performed the faster FSST test. Thereby, the FSST is a predicted risk of falls ${ }^{27}$ and the strength maybe help it. Predict risk of fall is important for this population because, in addition to the motor changes caused by disease $^{2}$, the aging process increases this risk ${ }^{28}$.

Taking into account that most falls happen while execution of dynamic tasks ${ }^{29}$, and people with PD may have symptoms that limit walk such gait freezing ${ }^{2}$, which combined with decreased of lower limb muscle strength $^{30}$ can improve balance disorders, thus 


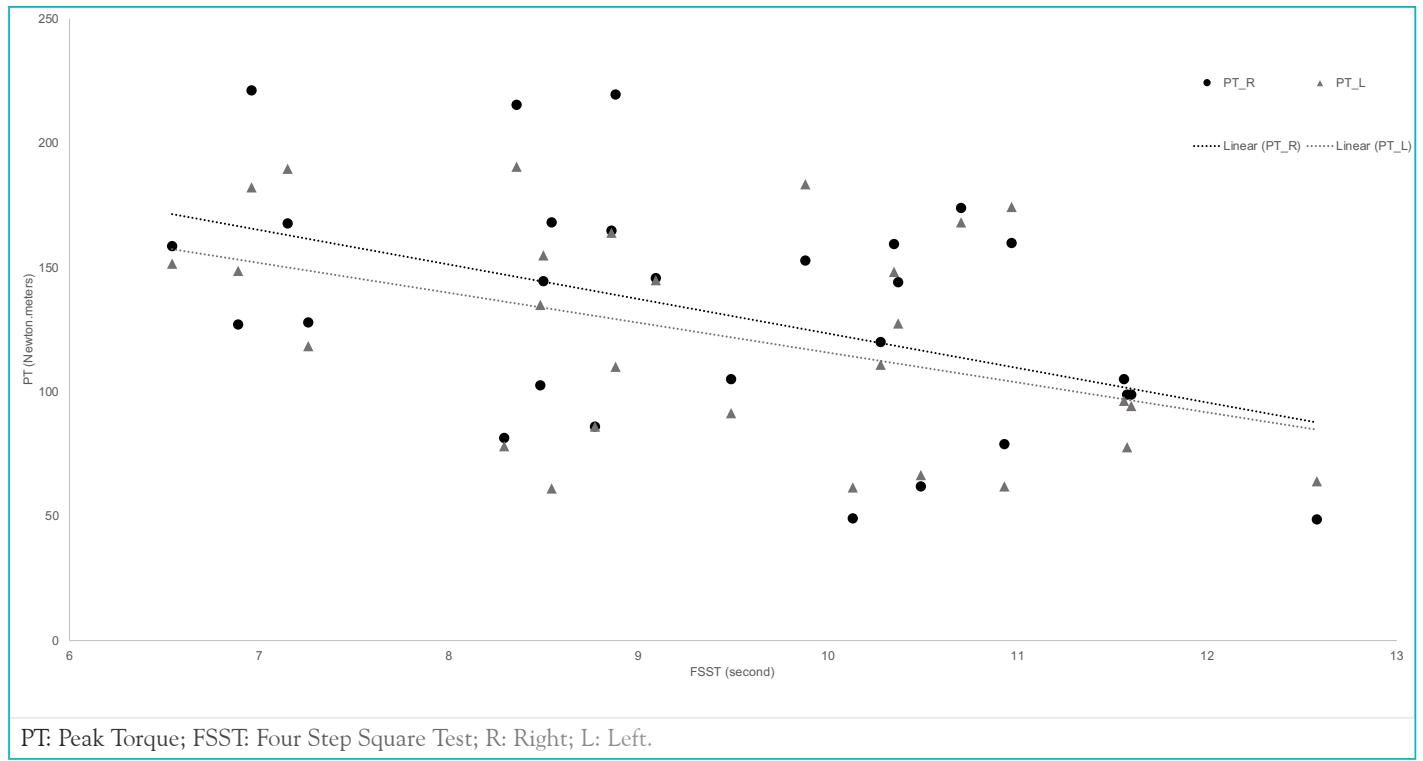

Figure 2. Correlation between FSST and PT.

emphasizing the importance of strength training ${ }^{31}$. The lower limb muscle strength has an important effect on the mobility helping the postural instability caused by the PD manifestations ${ }^{30}$.

Studies show that strength and resistance training improve balance in this population ${ }^{32,33}$, but few studies show an association between this physical capabilities, and less studies show this association with a simple and reliable test. This association can be explained due for production of movements is necessary a muscular contraction mediated by the somatic nervous system, as well as to develop strength ${ }^{34}$.

There are a few limitations associated with the present study. The first limitation is the small sample size which reduces the statistical power and reduces the generalizability of our findings. The second is not split individuals by stages of the modified Hoehn and Yahr scale neither gender. The third limitation is not considered the level of physical activity. Future studies could analyze each gender, stages of the modified Hoehn and Yahr scale and level of physical activity separately, besides increasing the sample size, moreover investigate in relation to laterality, the most affected side by the disease and to evaluate this population in the "off" medication period.

\section{CONCLUSION}

There is a negative correlation between functional balance and muscular strength of knee extensors in individuals with PD. For practical applications, the FSST can be used as a predictor of muscle strength decrease, as well as an alert for possible falls.

\section{ACKNOWLEDGEMENTS}

We would like to thank the Foundation for Research Support of the Federal District (FAPDF) and Coordination for the Improvement of Higher Education Personnel (CAPES) for their support.

\section{REFERENCES}

1. Obeso JA, Rodriguez-Oroz MC, Rodríguez M, Arbizu J, Gimenez-Amaya JM. The basal ganglia and disorders of movement: pathophysiological mechanisms. News Physiol Sci. 2002;17:51-5. https://doi.org/10.1152/ nips.01363.2001

2. Orcioli-Silva D, Barbieri FA, Simieli L, Rinaldi NM, Vitório R, Gobbi LTB. Effects of a multimodal exercise program on the functional capacity of Parkinson's disease patients considering disease severity and gender. Motriz: Rev Educ Fís. 2014;20(1):100-6. https://doi.org/10.1590/ s1980-65742014000100015

3. Hammond KG, Pfeiffer RF, LeDoux MS, Schilling BK. Neuromuscular rate of force development deficit in Parkinson disease. Clin Biomech. 2017;45:14-8. https:// doi.org/10.1016/j.clinbiomech.2017.04.003

4. Corcos DM, Chen CM, Quinn NP, McAuley J, Rothwell JC. Strength in Parkinson's disease: relationship to rate of force generation and clinical status. Annals of neurology. 1996;39(1):79-88. https://doi.org/10.1002/ana.410390112

5. Moreno Catalá M, Woitalla D, Arampatzis A. Central factors explain muscle weakness in young fallers with Parkinson's disease. Neurorehabil Neural Repair. 2013; 27 (8):753-9. https://doi.org/10.1177/1545968313491011

6. Schilling BK, Karlage RE, LeDoux MS, Pfeiffer RF, Weiss LW, Falvo MJ. Impaired leg extensor strength 
in individuals with Parkinson disease and relatedness to functional mobility. Parkinsonism Relat Disord. 2009;15(10):776-80. https://doi.org/10.1016/j.parkreldis. 2009.06.002

7. Protas EJ, Mitchell K, Williams A, Qureshy H, Caroline K, Lai EC. Gait and step training to reduce falls in Parkinson's disease. NeuroRehabilitation. 2005;20(3):183-90.

8. Hoehn MM, Yahr MD. Parkinsonism: onset, progression and mortality. Neurology. 1967;17(5):427-42. https://doi. org/10.1212/wnl.17.5.427

9. Shapiro A, Melzer I. Balance perturbation system to improve balance compensatory responses during walking in old persons. J Neuroeng Rehabil. 2010;7:32. https://doi. org/10.1186/1743-0003-7-32

10. Ondo W, Warrior D, Overby A, Calmes J, Hendersen $\mathrm{N}$, Olson S, Jankovic J. Computerized posturography analysis of progressive supranuclear palsy: a casecontrol comparison with parkinson's disease and healthy controls. Arch Neurol. 2000;57(10):1464-9. https://doi. org/10.1001/archneur.57.10.1464

11. Santos L, Fernandez-Rio J, Winge K, Barragán-Pérez B, González-Gómez L, Rodríguez-Pérez V, González-Díez V, Lucía A, Iglesias-Soler E, Dopico-Calvo X, FernándezDel-Olmo M, Del-Valle M, Blanco-Traba M, Suman OE, Rodríguez-Gómez J. Effects of progressive resistance exercise in akinetic-rigid Parkinson's disease patients: a randomized controlled trial. Eur J Phys Rehabil Med. 2017;53(5): 651-63. https://doi.org/10.1080/09638288.2016.1207104

12. Rossi-Izquierdo M, Soto-Varela A, Ernst A, RubioRodríguez JP, Santos-Pérez S, Sesar Á, Alberte-Woodward M, Guijarro-Del Amo M, Román-Rodríguez ES, FaraldoGarcía A, Zubizarreta-Gutiérrez A, Basta D. What could posturography tell us about balance problems in Parkinson's disease? Otol Neurotol. 2016;37(9):e326-e31. https://doi.org/10.1097/mao.0000000000001120

13. Dite W, Temple VA. A clinical test of stepping and change of direction to identify multiple falling older adults. Arch Phys Med Rehabil. 2002;83(11):1566-71. https://doi. org/10.1053/apmr.2002.35469

14. Whitney SL, Marchetti GF, Morris LO, Sparto PJ. The reliability and validity of the four square step test for people with balance deficits secondary to a vestibular disorder. Arch Phys Med Rehabil. 2007;88(1):99-104. https://doi.org/10.1016/j.apmr.2006.10.027

15. Blennerhassett JM, Jayalath VM. The four square step test is a feasible and valid clinical test of dynamic standing balance for use in ambulant people poststroke. Arch Phys Med Rehabil. 2008;89(11):2156-61. https://doi. org/10.1016/j.apmr.2008.05.012

16. McKee KE, Hackney ME. The four square step test in individuals with parkinson's disease: association with executive function and comparison with older adults. NeuroRehabilitation. 2014;35(2):279-89.

17. Li F, Harmer P, Fitzgerald K, Eckstrom E, Stock R, Galver J, Maddalozzo G, Batya SS. Tai Chi and postural stability in patients with Parkinson's disease. N Engl J Med. 2012;366(6):511-9. https://doi.org/10.1056/ nejmoa1107911
18. Schilling BK, Pfeiffer RF, Ledoux MS, Karlage RE, Bloomer RJ, Falvo MJ. Effects of moderate-volume, high-load lower-body resistance training on strength and function in persons with Parkinson's disease: a pilot study. Parkinsons Dis. 2010;2010:824734. https://doi. org/10.4061/2010/824734

19. Allen NE, Canning CG, Sherrington C, Lord SR, Latt MD, Close JC, O'Rourke SD, Murray SM, Fung VS. The effects of an exercise program on fall risk factors in people with Parkinson's disease: a randomized controlled trial. Mov Disord. 2010;25(9):1217-25. https://doi.org/10.1002/ mds.23082

20. Silva-Batista C, Corcos DM, Roschel H, Kanegusuku H, Gobbi LT, Piemonte ME, Mattos EC, DE Mello MT, Forjaz CL, Tricoli V, Ugrinowitsch C. Resistance training with instability for patients with Parkinson's disease. Med Sci Sports Exerc. 2016;48(9):1678-87. https://doi. org/10.1249/mss.0000000000000945

21. Goetz CG, Poewe W, Rascol O, Sampaio C, Stebbins GT, Counsell C, Giladi N, Holloway RG, Moore CG, Wenning GK, Yahr MD, Seidl L; Movement Disorder Society Task Force on Rating Scales for Parkinson's Disease. Movement Disorder Society Task Force report on the Hoehn and Yahr staging scale: status and recommendations. Mov Disord. 2004;19(9):1020-8. https://doi.org/10.1002/ mds. 20213

22. Folstein MF, Folstein SE, McHugh PR. "Mini-mental state". A practical method for grading the cognitive state of patients for the clinician. J Psychiatr Res. 1975;12(3):189-98. https://doi.org/10.1002/(sici)1099. 1166(199805)13:5<285::aid-gps753>3.3.co;2-m

23. Brucki SMD, Nitrini R, Caramelli P, Bertolucci PHF, Okamoto IH. Sugestões para o uso do mini-exame do estado mental no Brasil. Arqu NeuroPsiquiatr. 2003; 61(3-B):777-81. https://doi.org/10.1590/s0004$282 \times 2003000500014$

24. Craig CL, Marshall AL, Sjostrom M, Bauman AE, Booth ML, Ainsworth BE, Pratt M, Ekelund U, Yngve A, Sallis JF, Oja P. International physical activity questionnaire: 12 -country reliability and validity. Med Sci Sports Exerc. 2003;35(8):1381-95. https://doi.org/10.1249/01. mss.0000078924.61453.fb

25. Duncan RP, Earhart GM. Four square step test performance in people with Parkinson disease. J Neurol Phys Ther. 2013;37(1):2-8.

26. Malicka I, Chamela-Bilińska D, Koszewicz M, Dabrowska G, Woźniewski M. Parameters characterising isokinetic muscular activity in patients with Parkinson's disease: a pilot study. Rehabilitacja Medyczna. 2006;10(3):29-34.

27. Cleary K, Skornyakov E. Predicting falls in older adults using the four square step test. Physiother Theory Pract. 2017;33 (10):766-71. https://doi.org/10.1080/09593985.20 17.1354951

28. Finlayson ML, Peterson EW. Falls, aging, and disability. Phys Med Rehabil Clin N Am. 2010;21(2):357-73.

29. Simpson JM. S. R. Lord, C. Sherrington and H. B. Menz, Falls in Older People: Risk Factors and Strategies for Prevention, Cambridge University Press, 2001, 250 pp pbk 
$£ 29 \cdot 95$, ISBN 0521589 649. Ageing Soc. 2001;21(5):

667-75. https://doi.org/10.1017/s0144686x02258511

30. Durmus B, Baysal O, Altinayar S, Altay Z, Ersoy Y, Ozcan C. Lower extremity isokinetic muscle strength in patients with Parkinson's disease. J Clin Neurosci. 2010;17(7):893-6. https://doi.org/10.1016/j.jocn.2009.11.014

31. Paul SS, Canning CG, Song J, Fung VS, Sherrington C. Leg muscle power is enhanced by training in people with Parkinson's disease: a randomized controlled trial. Clin Rehabil. 2014;28(3):275-88. https://doi. org/10.1177/0269215513507462

32. Combs SA, Diehl MD, Chrzastowski C, Didrick N, McCoin B, Mox N, Staples WH, Wayman J. Communitybased group exercise for persons with Parkinson disease: a randomized controlled trial. NeuroRehabilitation. 2013;32(1):117-24.

33. Carvalho A, Barbirato D, Araujo N, Martins JV, Cavalcanti JLS, Santos TM, Coutinho ES, Laks J Deslandes AC. Comparison of strength training, aerobic training, and additional physical therapy as supplementary treatments for Parkinson's disease: pilot study. Clin Interv Aging. 2015;10:183-91. https://doi.org/10.2147/cia.s68779

34. Purves D, Augustine GJ, Fitzpatrick D, Hall WC, LaMantia AS, McNamara JO, White LE, editors. Neuroscience. 4th ed. Sunderland: Sinauer; 2007.

\section{AUTHORS:}

SACHA CLAEL

Master's degree in Physical Education, University of Brasília (UNB). Brasília, DF, Brazil.

E-mail: sachaclael@hotmail.com

Orcid: https://orcid.org/0000-0002-6159-3490

FILIPE DINATO DE LIMA

Master's degree in Health Sciences, University of Brasília (UNB). Brasília, DF, Brazil.

E-mail: filipedinato@hotmail.com

Orcid: https://orcid.org/0000-0001-5748-7540

ELAINE CRISTINA DA SILVA BRANDÃO

Graduate's degree in Physical Education. Faculty of Physical Education. University of Brasilia (UNB). Brasilia, DF. Brazil.

E-mail: elacsb13@gmail.com

Orcid: https://orcid.org/0000-0003-0765-945X

JHONATAN CONRADO RODRIGUES

Graduate's degree in Physical Education. Faculty of Physical Education. University of Brasilia (UNB). Brasilia, DF. Brazil.

E-mail: jhonatanconradodocs@gmail.com

Orcid: https://orcid.org/0000-0002-4639-4645

CAMILA Wells DAMATO MARCELINO

Master's degree in Physical Education. Faculty of Physical Education. University of Brasilia (UNB). Brasilia, DF Brazil.

E-mail: camilawells123@gmail.com

Orcid: https://orcid.org/0000-0002-2537-8558

RAFAELA DO VALE PINHEIRO

Graduate's degree in Physiotherapy. Catholic University of Brasília (UCB).

Brasília, DF. Brazil.

E-mail: faleladovale@gmail.com

Orcid: https://orcid.org/0000-0001-7533-5241

José Celi NetO

Master's degree in Applied Sciences and Sports Games. The University of

Matanzas (UM). Matanzas, MTZ, Cuba. Faculty of Physical Education.

University of Brasilia (UNB). Brasília, DF, Brazil.

E-mail: zecaceli55@hotmail.com

Orcid: https://orcid.org/0000-0001-9706-178X

LíDIA MARA AGUIAR BEZERRA

Doctorate's degree in Physical Education, Catholic University of Brasília (UCB).

Professor at University of Brasília (UNB). Brasília, DF. Brazil.

E-mail: lidia.bezerra@gmail.com

Orcid: https://orcid.org/0000-0003-0661-6298 